Thorax (1964), 19, 515.

\title{
Familial interstitial pulmonary fibrosis
}

\author{
E. W. HU G HE S \\ From Tehidy Hospital, Camborne, Cornwall
}

In 1944 Hamman and Rich first described a disease that caused an acute diffuse interstitial fibrosis of the lungs, and which resulted in the death of four patients within six months of the onset of symptoms. Since then countless further cases have been reported in the literature, and our knowledge of the subject has advanced.

It is recognized that the interstitial fibrotic process may be localized as well as diffuse; that more often than not the disease follows a more protracted course than it did in the cases first described; that natural remissions may sometimes occur; and that corticosteroid therapy is sometimes effective in 'suppressing' the disease prosess and delaying its progress.

Little, however, has been learned about its causation. It is known that interstitial pulmonary fibrosis, may be the consequence of a variety of pulmonary diseases, such as sarcoidosis or chronic pulmonary tuberculosis, or that it may occur as a manifestation of various systemic diseases such as scleroderma. But in the vast majority the aetiology remains obscure, and we are left with a heterogeneous group of cases which many authors are wont to class together under the general heading of Hamman-Rich syndrome. This may be inadvisable when it is still not known whether the acute, subacute, and chronic types represent varying reactions to one, or more than one, aetiological agent, and on this account Scadding (1960) recommends the use of descriptive terms.

One of the most remarkable features at the present time is the absence in the English literature of any examples of the familial type of the disease which has been recorded by several authors in America and on the Continent. Here I record three such cases of diffuse interstitial pulmonary fibrosis from one family who have been under my care for the past three years and who also manifest the acute, subacute, and chronic forms of the disease.

\section{CASE REPORTS}

CASE 1 J.S., a woman aged 30. Single. Occupation: housekeeper.
This young lady had a normai chest radiograph in January 1959 and was in good health until January 1961, when breathlessness on exertion was first experienced. It became progressively more severe, and when admitted to another hospital at the end of May she was acutely ill and had a slight productive cough. On examination there was central cyanosis, and crepitations were audible at the bases of both lungs. Clubbing was not present. The temperature was raised, reaching on occasions $105^{\circ} \mathrm{F}$., and there was a sinus tachycardia of $140 /$ minute. $\mathrm{Hb} 68 \%$; W.B.C. 9,000 per c.mm.; polymorphs $46 \%$; lymphocytes $38 \%$; monocytes $16 \%$; E.S.R. $131 \mathrm{~mm}$. in one hour. The chest radiograph showed generalized fine mottling throughout both lungs and dilatation of the pulmonary artery. The fever was uninfluenced by broad-spectrum chemotherapy, but settled by lysis when the antibiotics were withdrawn during the third week. In the meantime the breathlessness had become so severe that speech was barely possible, and, in the middle of June, she was transferred to Tehidy Hospital for further investigation.

The chest signs were as before except for an increase in the rate of respiration from 20 to 40 excursions per minute. The heart sounds were normal and there was no evidence of heart failure. The blood pressure was $120 / 70 \mathrm{~mm}$. $\mathrm{Hg}$; $\mathrm{Hb} 54 \%$; R.B.C. 2,550,000 per c.mm.; W.B.C. 5,200 per c.mm.; polymorphs $62 \%$; lymphocytes $31 \%$; monocytes $1 \%$; myelocytes $2 \%$; metamylocytes $4 \%$; E.S.R. $77 \mathrm{~mm}$. in one hour ; blood group A Rhesus negative-; serum albumin 4 g. $/ 100 \mathrm{ml}$.; serum globulin 2.8 g. $/ 100 \mathrm{ml}$.; alpha 1 globulin $0.3 \mathrm{~g} . / 100 \mathrm{ml}$; alpha 2 globulin 0.5 g. $/ 100 \mathrm{ml}$.; beta globulin $0.3 \mathrm{~g} . / 100 \mathrm{ml}$. ; gamma globulin 1.3 g. $/ 100 \mathrm{ml}$.; R.A. (latex) test negative; L.E. (latex) test negative; Mantoux 1/100 O.T. negative. The chest radiograph showed extension of mottling with areas of confluence in the left middle and right lower zones (Fig. 1). All other measures having failed, adrenocorticotrophic hormone (A.C.T.H.) was given on an empirical basis, and from that time her condition slowly but steadily improved. Within four days the pulse rate fell from 120 to 90 per minute, the dyspnoea became noticeably less, and the chest radiograph showed considerable clearing of the scattered mottling. A week later dyspnoea was only mild, the weight had increased by $6 \mathrm{lb}$., crepitations were no longer audible, and radiologically the picture was one of continuing resolution. One month after admission she was well enough for a lung 


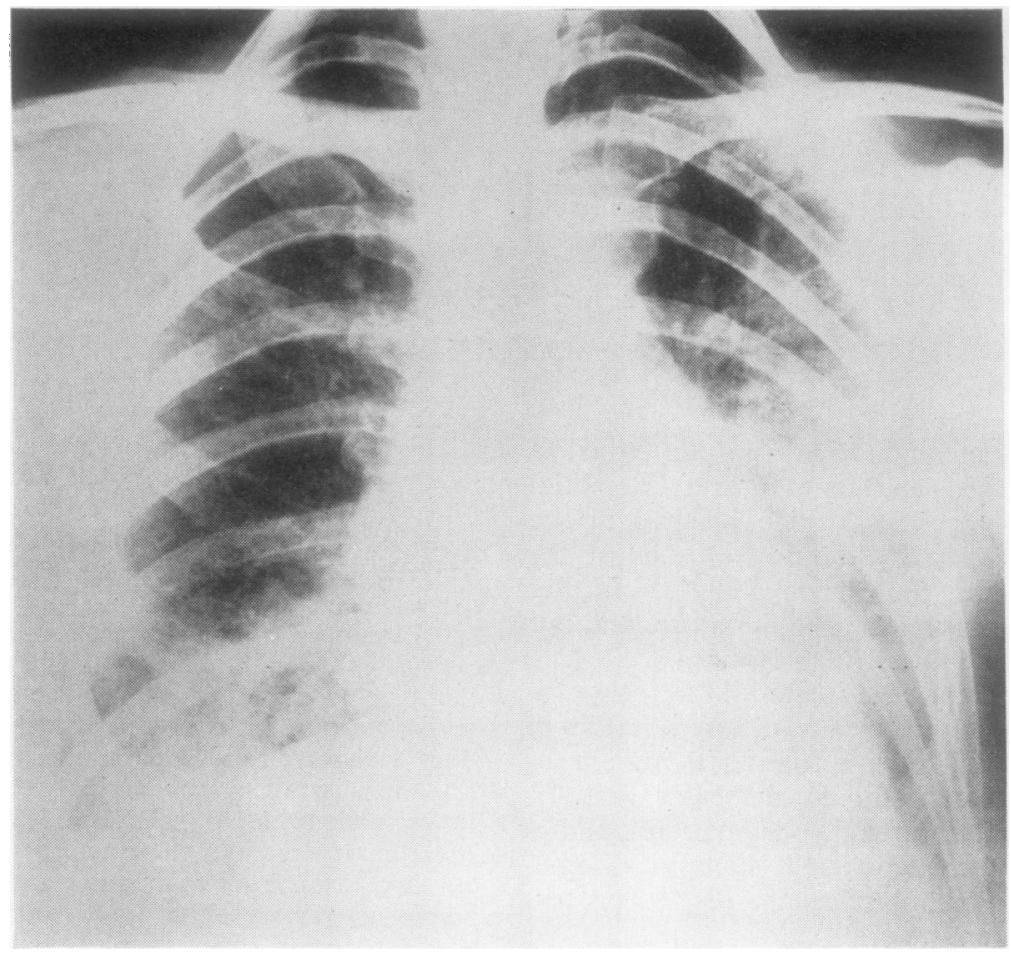

FIG. 1. Case 1. Chest radiograph, June 1951.

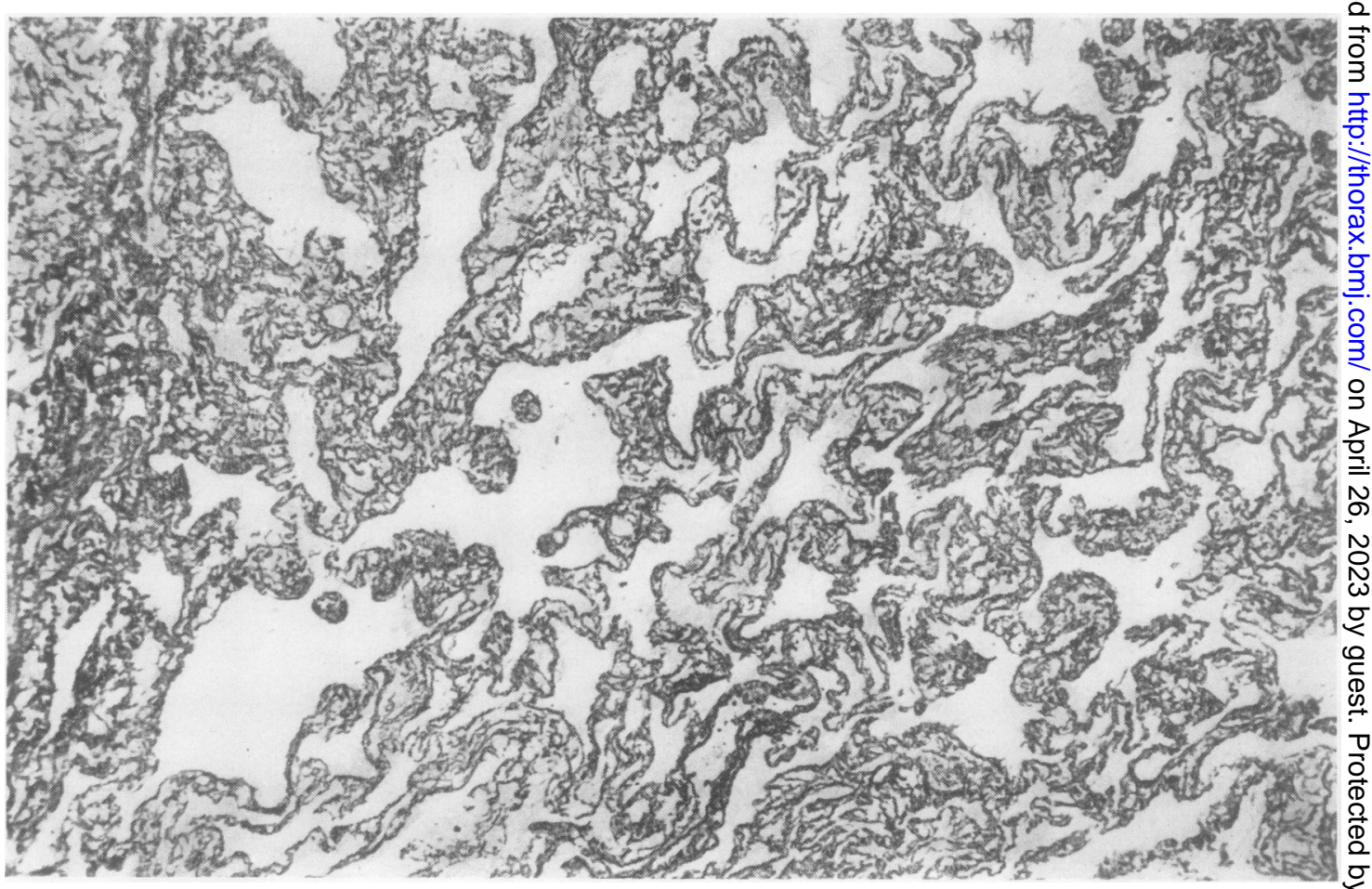

FIG. 2. A section of lung showing the reticulin increase causing thickening of the walls of the air spaces so characteristic of each of the three cases. Silver impregnation, $\times 90$. 


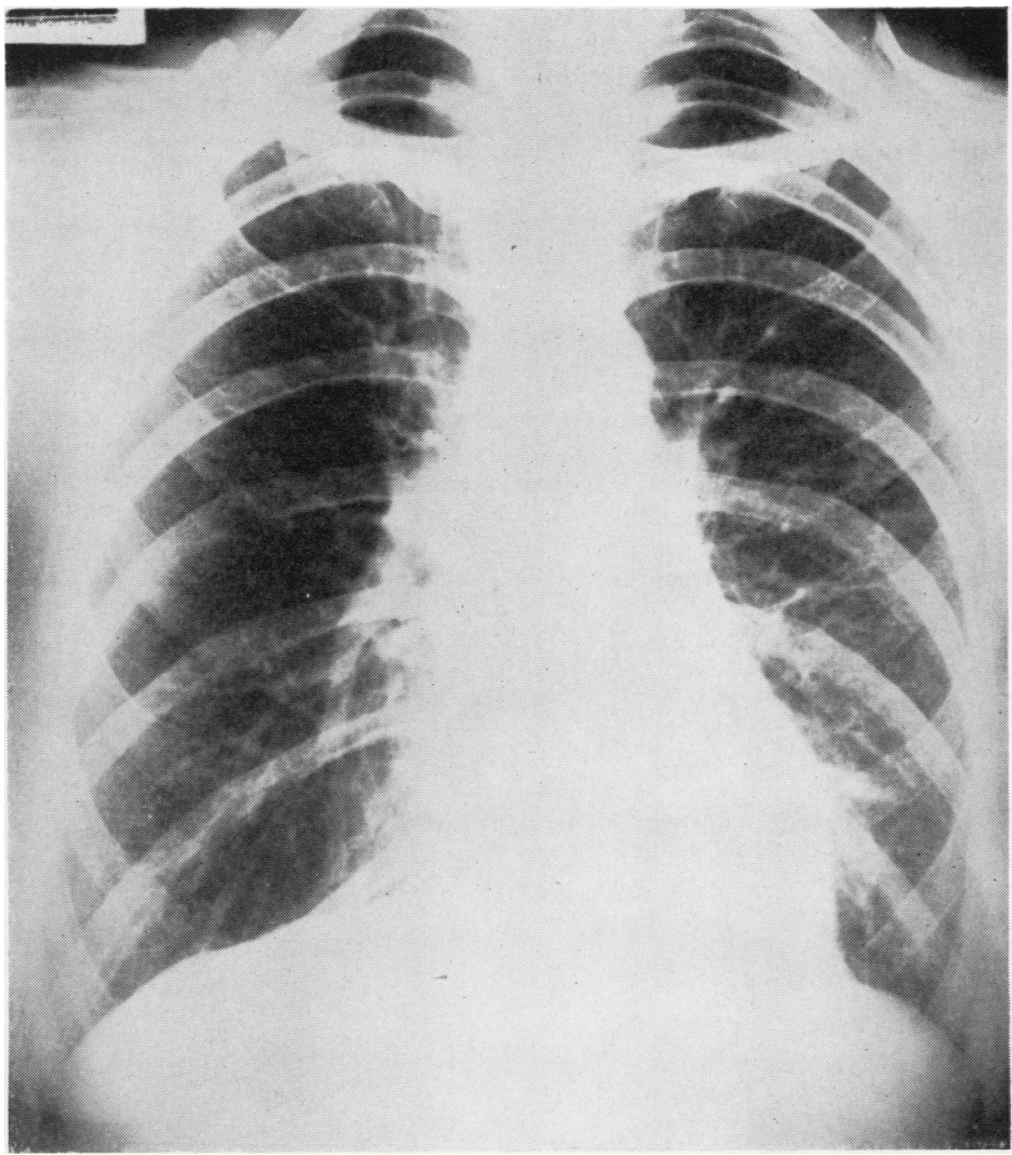

FIG. 3. Case 1. Chest radiograph, October 1961.

biopsy to be taken, the tip of the lingular segment being removed through a small thoracotomy incision. The sections were forwarded to Professor J. Gough, who reported as follows:

'The sections show chronic inflammation of the lung which is mainly interstitial. There is dense accumulation of lymphocytes, plasma cells, and histiocytes. These, together with an increase of reticulin, have produced great thickening of the walls of the alveoli and other distal air spaces (Fig. 2). There are also inflammatory cells and fibrosis obliterating some of the air spaces, but this feature is less prominent than the interstitial fibrosis. The condition is that usually described under the title "idiopathic interstitial fibrosis" but it is also recorded as a variant of Hamman-Rich disease. (This type of fibrosis seems to be by far the commonest cause of honeycomb lung.) It is distinguishable from histiocytosis and from eosinophilic xanthomatous granuloma.'

Progress was maintained on $15 \mathrm{mg}$. prednisolone daily, and when discharged in September 1961 the patient was much improved and considered the exer- cise tolerance to be $75 \%$ of normal. Radiologically some fine punctate mottling was still evident, but the overall impression was one of resolution. A month after her return home her breathing was much better (exercise tolerance $95 \%$ of normal) and the chest radiograph (Fig. 3) showed, for the first time, clear lung fielils and a normal sized pulmonary artery. At this stage the dose of prednisolone was reduced steadily without noticeable adverse effect, and in December 1961 it proved possible to stop corticosteroids and to allow a return to work. Progress thereafter was satisfactory until 1962 when, during a routine antenatal examination, a refractory anaemia was again found. In September of that year she was delivered of a healthy child without incident; but within six months dyspnoea, cough, and lethargy recurred. Clinically, there was obvious pallor and toxaemia, and her weight had fallen by 1 stone. There was still no clubbing or radiological deterioration, but crepitations were again present on auscultation. Haematological examination showed $\mathrm{Hb} 53 \%$; W.B.C. 6.400 per c.mm. ; polymorphs $57 \%$; lympho- 
cytes $23 \%$; monocytes $15 \%$; metamyelocytes $4 \%$; myelocytes $1 \%$; polymorph alkaline phosphatase score 302 (normal 14/100). This was interpreted as showing a leukaemoid reaction likely to be associated with a chronic toxic condition. Histamine test meal-free acid present. Serum albumin $3 \mathrm{~g} . / 100 \mathrm{ml}$. ; serum globulin $4.6 \mathrm{~g} . / 100 \mathrm{ml}$.; alpha/globulin ratio $0.65: 1$; alpha 1 globulin 0.6 g. $/ 100 \mathrm{ml}$; alpha 2 globulin 1.0 g. $/ 100 \mathrm{ml}$.; beta globulin 0.9 g. $/ 100 \mathrm{ml}$.; gamma globulin $2 \cdot 1 \mathrm{~g} . / 100 \mathrm{ml}$.

All conventional methods for the correction of the anaemia having failed, corticosteroids were again given, and within two days the patient felt very much better. After a further month she had regained her lost weight, the lungs were clear on auscultation, the haemoglobin had risen to $67 \%$, and the E.S.R. had fallen to $20 \mathrm{~mm}$. in one hour. Serum albumin $3.3 \mathrm{~g}$./ $100 \mathrm{ml}$. ; serum globulin 2.9 g. $/ 100 \mathrm{ml}$. with a corresponding decrease in all the globulin fractions. Since that time she has remained clinically well so long as corticosteroid treatment has continued, the radiographic improvement has been maintained, and the $\bar{\omega}$ main feature of her health has been a susceptibility to descending respiratory infection. The haemoglobin varies from 70 to $80 \mathrm{~g}$. per $100 \mathrm{ml}$.

CASE 2 R.G., a woman aged 39. Housewife and sister of case 1 .

This patient's illness presented in December 1961 with what was thought to be a bronchitis. The cough was productive of some mucoid sputum, and there was also some wheeze and shortness of breath, but $\vec{\theta}$ the features that caused concern were loss of weight 8 and persistent tiredness. Clinically she looked pale $\vec{G}$ and rather older than her stated age. There was a sinus tachycardia of $100 /$ minute but no fever. There was no clubbing or cyanosis. Chest expansion and air entry were good, and on auscultation crepitations

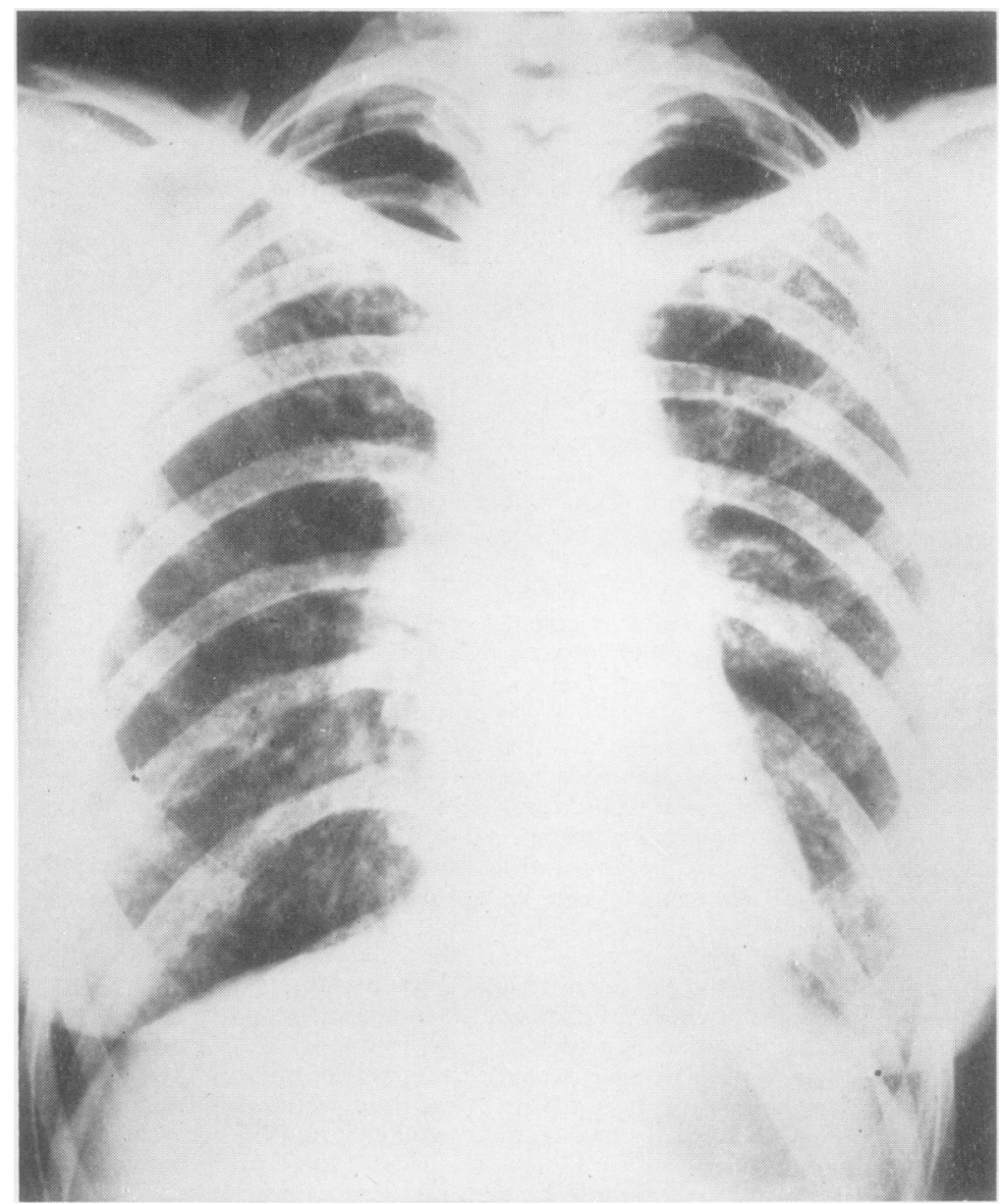

FIG. 4. Case 2. Chest radiograph, January 1962. 
were heard at the right apex and left base. The chest radiograph showed coarse mottling in the mid and lower zones, most marked on the left (Fig. 4). A provisional diagnosis of pulmonary tuberculosis was made, and the patient was admitted for further investigation, the results being as follows: $\mathrm{Hb} 84 \%$; W.B.C. 8,000 per c.mm. with a normal differential count except for an eosinophilia of $10 \%$; E.S.R. $100 \mathrm{~mm}$. in one hour ; blood group $\mathrm{O} R \mathrm{R}$ positive ; serum albumin $3.3 \mathrm{~g} . / 100 \mathrm{ml}$. ; serum globulin $3.7 \mathrm{~g} . /$ $100 \mathrm{ml}$.; albumin/globulin ratio 0.9:1; alpha 1 globulin 0.4 g. $/ 100 \mathrm{ml}$.; alpha 2 globulin 0.5 g. $/ 100$ ml. ; beta 1 globulin $0.3 \mathrm{~g} . / 100 \mathrm{ml}$; beta 2 globulin 0.7 g. $/ 100 \mathrm{ml}$. ; gamma globulin 1.8 g. $/ 100 \mathrm{ml}$. ; R.A. (latex fixation) test negative; L.E. test negative ; sputum negative for tubercle bacilli ; Kveim test negative; Mantoux negative; vital capacity 1.5 litres; M.B.C. 50 litres/min. ; F.E.V.1 $86 \%$; P.E.F. 355 litres $/ \mathrm{min}$. This patient's symptoms cleared within a week without treatment but the radiographic changes persisted, and, in the absence of a diagnosis, she agreed to lung biopsy, which was performed in March 1962. Sections were again forwarded to Professor J. Gough, who reported as follows:

'The sections show diffuse interstitial inflammation with well marked thickening of the walls of the alveoli and other distal air spaces. This is an example of the same kind of idiopathic lung fibrosis seen in case 1. In addition to lymphocytes and plasma cells there are a few eosinophils, but I do not regard it as an example of eosinophilic granuloma.'

When taking prednisolone the exercise tolerance and general health (both of which the patient considered had already returned to normal) further improved, and the chest radiograph showed resolution of all the mottling save for that in the first interspaces. The patient left hospital at the end of March 1962. Throughout the remainder of that year she continued in normal health on $10 \mathrm{mg}$. prednisolone daily, and by November the radiological appearances had reached their optimum, the film then showing only some very minimal mottling at the apices. By March 1963 the E.S.R. had fallen to $9 \mathrm{~mm}$. in one hour. So great was the clinical and radiological improvement that a natural remission was suggested, and the dose of prednisolone was cautiously reduced. No upset resulted, and it was possible to stop corticosteroids altogether at the end of August 1963. No noticeable deterioration in the health and exercise tolerance occurred, but serial chest radiographs showed slight but definite extension of the biapical mottling, and the E.S.R. rose over the course of the next four months to $113 \mathrm{~mm}$. in one hour. In March 1964 it was possible, for the first time, to estimate the pulmonary diffusing capacity by the single-breath method using carbon monoxide, and the resultant low figure of $10 \mathrm{ml} . / \mathrm{min} . / \mathrm{mm}$. $\mathrm{Hg}$ suggested that the disease was again active. With the reintroduction of $10 \mathrm{mg}$. of prednisolone daily there was an immediate symptomatic improvement, the E.S.R. fell to $21 \mathrm{~mm}$. in one hour, and she was once again able to do all the heavy housework.
CASE 3 B.S., a woman aged 72. Mother of cases 1 and 2 .

This patient first experienced breathlessness on exertion in June 1960 at the age of 69. Four months later when she attended a mass radiography unit the breathlessness had improved, but the chest radiograph (Fig. 5) showed extensive pulmonary fibrosis most noticeable at the periphery of both lungs. A month later, when first referred to the chest clinic, she had bronchitis but appeared to be responding to symptomatic treatment, and the cough had almost disappeared. On examination she was of short stature and medium build. There was no evidence of toxaemia, and the only significant abnormality found was an area of crepitations at the base of the right lung. The blood pressure was $180 / 90 \mathrm{~mm}$. Hg. It was considered that her sporadic symptoms were due to bronchitis and that the pulmonary fibrosis was probably of post-inflammatory origin. The subjective and clinical improvement continued for two years until September 1962, when severe breathlessness returned and she complained of increasing tiredness. On examination her weight had fallen by $1 \frac{1}{2}$ stones, and there was obviously respiratory insufficiency with all the signs of a diffusion defect. There was also active clubbing and cyanosis, and auscultation revealed showers of crepitations throughout both lungs. The chest radiograph showed extension of the pulmonary fibrosis. Hb $102 \%$; W.B.C. 13,200 per c.mm. with a normal differential; blood group $\mathrm{O} R \mathrm{~h}$ negative; serum albumin 4.0 g. $/ 100 \mathrm{ml}$. ; serum globulin $3.5 \mathrm{~g} . /$ $100 \mathrm{ml}$.; alpha 1 globulin $0.4 \mathrm{~g} . / 100 \mathrm{ml}$.; alpha 2 globulin 0.9 g. $/ 100 \mathrm{ml}$; beta globulin $0.8 \mathrm{~g} . / 100 \mathrm{ml}$. ; gamma globulin 1.4 g./100 ml.; blood urea $21 \mathrm{mg}$./ 100 ml.; R.A. (latex) fixation test negative; Mantoux positive; sputum negative for tubercle bacilli.

The relationship to cases 1 and 2 was now known, and a diagnosis of familial interstitial pulmonary fibrosis was made. Treatment with prednisolone resulted in an immediate symptomatic improvement: when the patient was seen a month later the breathlessness was much less, the fever had settled, and fewer crepitations were audible on auscultation; the radiological appearances were unchanged. Three months later she had another respiratory infection which responded quite satisfactorily to broadspectrum chemotherapy, but despite a regular maintenance dose of prednisolone, $7.5 \mathrm{mg}$., there was a steady deterioration in the exercise tolerance until an increase in the daily dose of prednisolone to $10 \mathrm{mg}$. brought about a perceptible clinical improvement and a fall in the gamma globulin to $1.0 \mathrm{~g} . / 100 \mathrm{ml}$. This improvement, however, was again short-lived, for within three months severe breathlessness returned and the chest radiograph (Fig. 6) showed that honeycomb shadowing had developed at the periphery of both lungs. Another increase in the dose of prednisolone to $15 \mathrm{mg}$. daily helped to keep her in comfort but did not prevent further deterioration, and she died suddenly in January 1964, 16 months after the onset of symptoms. 


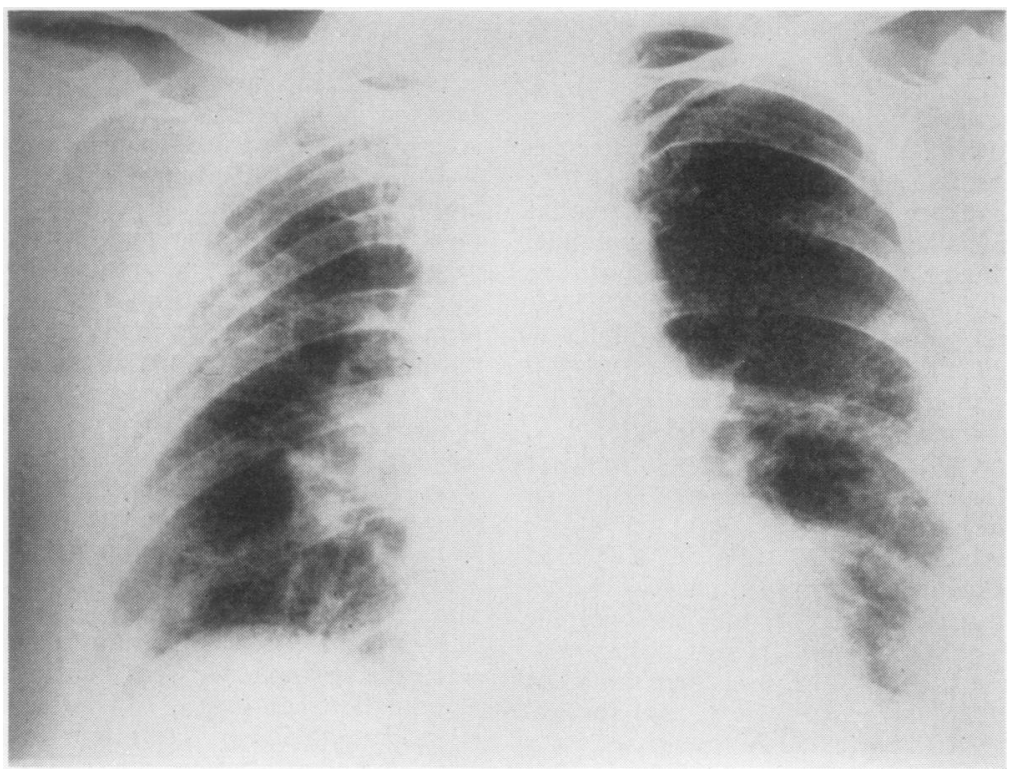

FIG. 5. Case 3. Chest radiograph, Octoher 1960.

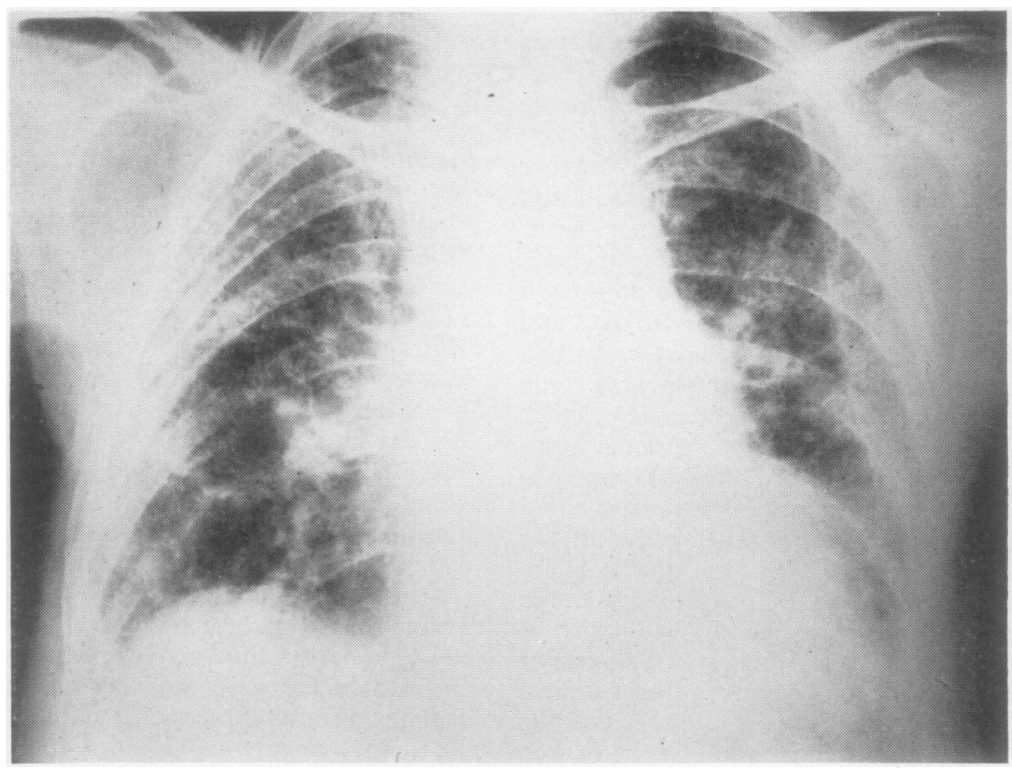

FIG. 6. Case 3. Chest radiograph, September 1963.

Necropsy was carried out 18 hours after death by Dr. R. Salm, and significant findings were limited to the thorax. The heart weighed $310 \mathrm{~g}$. and was distended and hypertrophied on the right side. The wall of the left ventricle measured $1.7 \mathrm{~cm}$., that of the right $0.8 \mathrm{~cm}$. in diameter. The cusps and valves were healthy. The coronary arteries showed some atheromatosis. The bronchi showed reddened mucous membranes and contained some mucoid secretion.

The lungs were found to be somewhat collapsed when the thorax was opened, but were normal in $\mathbb{\mathbb { Q }}$ shape and size. Their external appearances were 


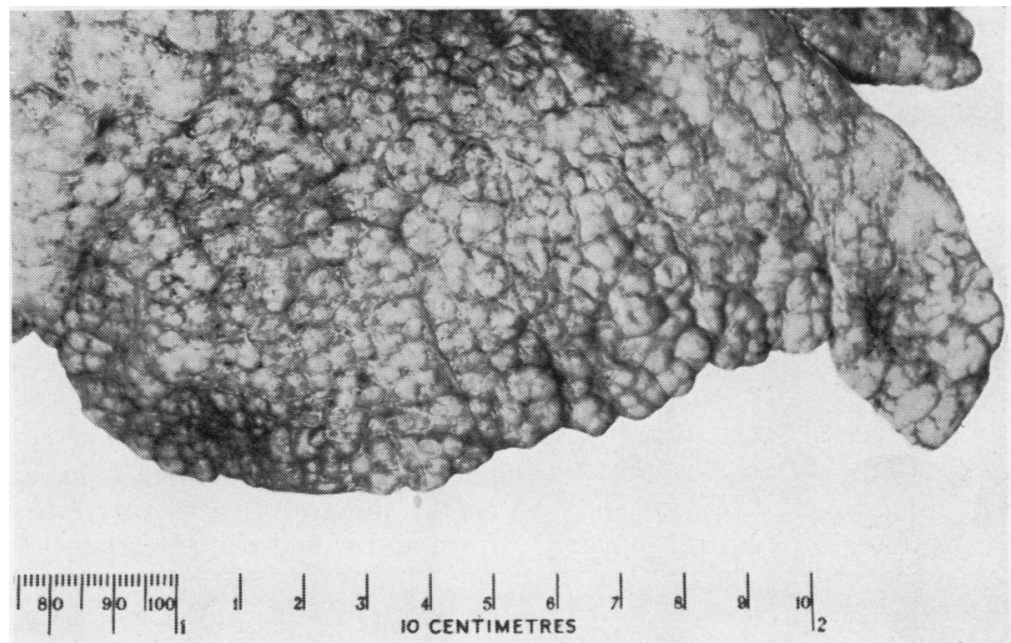

FIG. 7. Case 3. Showing the hobnailed pattern produced by small groups of emphysematous bronchioles.

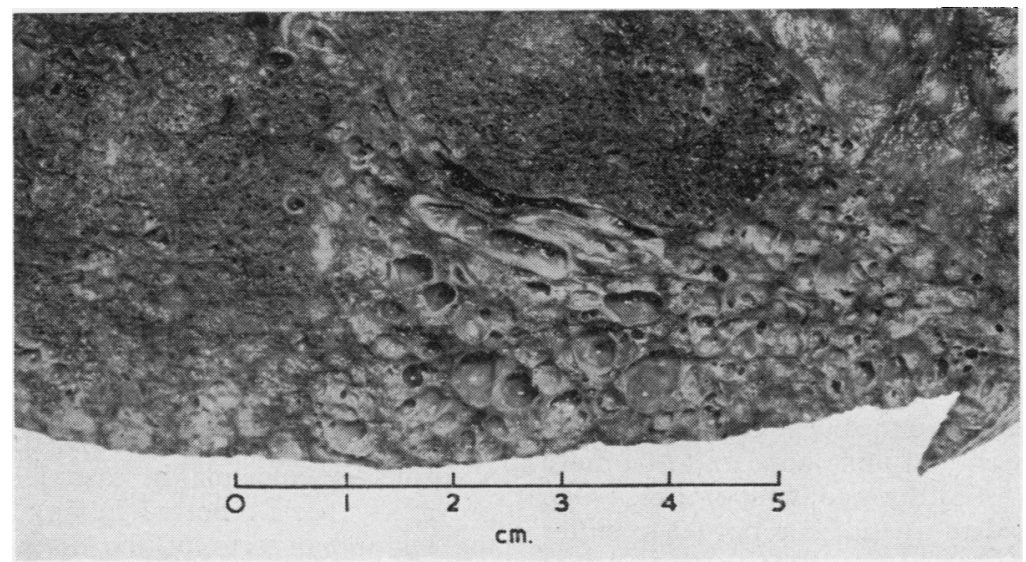

FIG. 8. Case 3. Section of right lung showing the honeycomb areas at the periphery of the lung.

unusual, displaying a hobnailed pattern (Fig. 7) due to small groups of emphysematous bronchioles measuring about $0.5 \mathrm{~cm}$. in diameter, surrounded by slightly sunken, congested septa. Occasionally these individual cysts were larger and bullous. On slicing, the right lung showed few macroscopical abnormalities apart from the honeycomb areas at the periphery (Fig. 8). The intact left lung was forwarded to Professor J. Gough, who reported as follows:

'The section shows diffuse interstitial fibrosis and honeycomb lung. The findings include features found in cases 1 and 2 . There is infiltration with lymphocytes and plasma cells but there are additional features which are probably due to this case being of longer duration. There is well marked cystic, i.e. honeycomb, formation at the periphery (Fig. 9) and fibrosis is dense; there is considerable smooth muscle hyperplasia; the blood vessel walls are greatly thickened. The dilated air spaces are lined by columnar epithelium which in places shows adenomatous hyperplasia. These appearances (Gough, 1959) are the ones which I have seen in other cases of honeycomb lung for which no cause could be found and which did not have the appearances of scleroderma (diffuse systemic sclerosis) or eosinophilic xanthomatous granuloma.'

\section{FAMILY HISTORY}

Details of the family history (Fig. 10) were difficult to obtain as the relatives of the mother (case 3) were scattered over a wide rural area and 


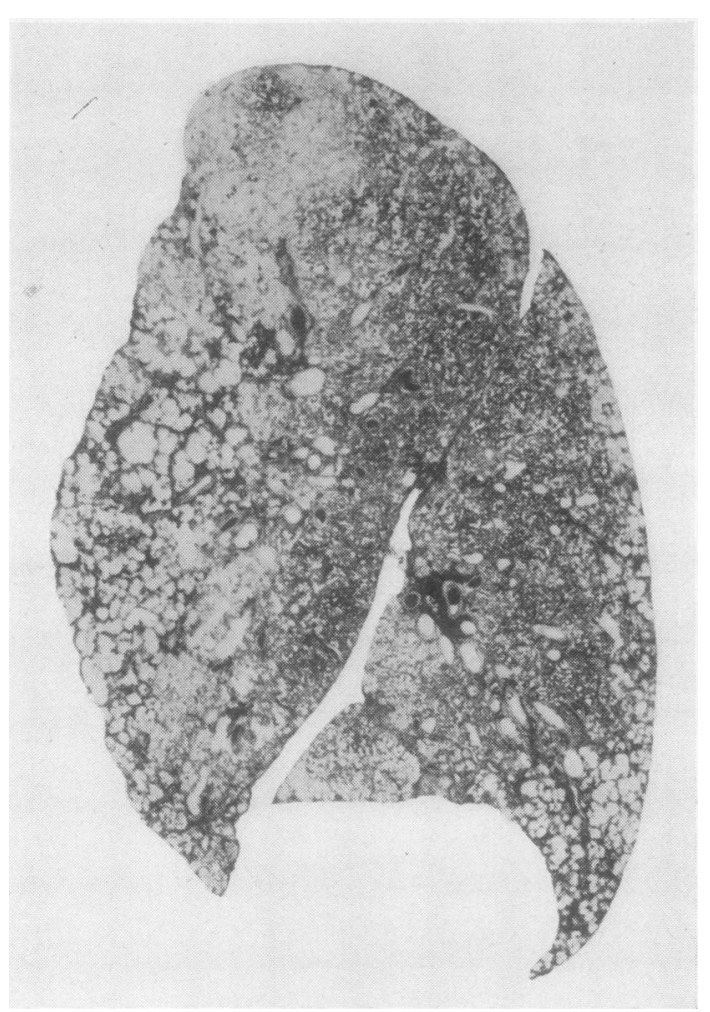

FIG. 9. Case 3. Whole section of left lung showing the typical honeycombed (cystic) appearances at the periphery.

were often reluctant to attend for clinical and radiological examination; but all the survivors remain actively well and none appears to be more breathless than healthy contemporaries. One sister, who refused to attend, is reported to suffer from rheumatoid arthritis. It is also regretted that no precise information is available regarding the cause of death of the three sisters who died, since all the deaths occurred at home. The surviving members of the second and third generation have been examined and found to be healthy.

\section{COMMENT}

One of the intriguing features of the three cases presented is that the illness appeared in a mother and her two daughters within the space of 18 months when all three had lived apart from one another in different surroundings for a number of years. It is true that the chest radiograph of the mother (case 3), the first to be seen in June 1960, showed extensive interstitial pulmonary fibrosis of some maturity, but careful questioning failed to elicit any previous history of dyspnoeic episodes, and increasing breathlessness did not develop until 1962. Several cases have been reported in the literature in which the disease was genetically transmitted but its occurrence, in this series, in the mother and daughters at the same time suggests that some other factor or factors may also have played a part. As McKusick and Fisher (1958) pointed out, the genetic contribution is often complex or polygenic in nature, and frequently environmental factors 'collaborate' in the aetiology and pathogenesis.

Another point of interest is that the three related patients should each have a different type of the disease. Case 1 was typical of the acute form and would almost certainly have died within six months of the onset of symptoms but for corticosteroid therapy. Case 2, on the other hand, was not acutely ill at any stage and after a week's rest considered her health normal and incapable of further improvement until after corticosteroids had been given. Although there was some radiological deterioration and elevation of the sedimentation rate after prednisolone was stopped, the patient remained clinically well, and the behaviour of the disease to date is consistent with the subacute form. Case 3 is an example of chronic interstitial pulmonary fibrosis, for breathlessness, when it developed, was progressive, and the disease followed a slowly downhill course until she died. This behaviour supports the unitarian concept that the acute, subacute, and chronic types all represent varying reactions to the aetiological agent or agents.

The third unusual feature is the occurrence of a refractory anaemia in case 1 . This has never previously been reported in any of the cases of the idiopathic form of the disease, and appears to be related in some way to the pulmonary condition. The haemoglobin readings have always been low when the disease is active and have invariably risen during corticosteroid-induced or spontaneous remission; and the coincidental marked elevation

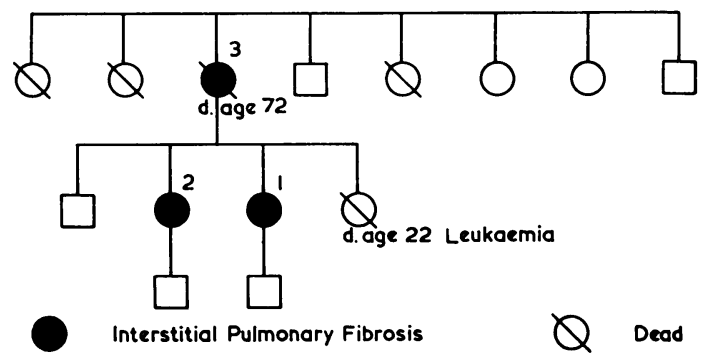

FIG. 10. Pedigree of family. 
TABLE I

\begin{tabular}{|c|c|c|c|c|c|c|c|c|}
\hline Reported by & Relationship & Family History & Sex & $\begin{array}{l}\text { Age and Yea } \\
\text { Onset of Symp } \\
\text { and Radiogra } \\
\text { Changest }\end{array}$ & $\begin{array}{l}\text { ar of } \\
\text { ptoms } \\
\text { aphic } \\
\text { st }\end{array}$ & $\begin{array}{l}\text { Type of } \\
\text { Dise ase* }\end{array}$ & $\left|\begin{array}{c}\text { Duration } \\
\text { of } \\
\text { Symptcms }\end{array}\right|$ & Fate \\
\hline $\begin{array}{l}\text { Sandoz (1907) } \\
\text { Sandoz (1907) }\end{array}$ & $\begin{array}{l}\text { Female } \\
\text { Twin sister }\end{array}$ & $\begin{array}{l}\text { Mother healthy } \\
\text { Father ? Pulm. } \\
\text { tuberculosis }\end{array}$ & $\begin{array}{l}\mathrm{F} \\
\mathbf{F}\end{array}$ & $\begin{array}{l}16+\mathrm{yr} . \\
18 \mathrm{yr}\end{array}$ & $\begin{array}{l}1901 \\
1902\end{array}$ & $\begin{array}{l}\text { Subacute } \\
\text { Acute }\end{array}$ & $\begin{array}{l}1 \frac{1}{2} \mathrm{yr} \\
6 \mathrm{mth}\end{array}$ & $\begin{array}{c}\text { Died aged } 18 \mathrm{yr} . \\
1902 \\
\text { Died aged } 18 \mathrm{yr} . \\
1903\end{array}$ \\
\hline $\begin{array}{l}\text { Peabody et al. (1950) } \\
\text { MacMillan (1951) }\end{array}$ & $\begin{array}{l}\text { Female } \\
\text { Identical twin } \\
\text { sister }\end{array}$ & $\begin{array}{l}\text { Nil } \\
\text { Nil }\end{array}$ & $\begin{array}{l}F \\
F\end{array}$ & $\begin{array}{l}44 \mathrm{yr} \text {. } \\
43 \mathrm{yr} \text {. }\end{array}$ & $\begin{array}{l}1944 \\
1943\end{array}$ & $\begin{array}{l}\text { Subacute } \\
\text { Chronic }\end{array}$ & $\begin{array}{l}3 \frac{1}{2} \mathrm{yr} . \\
7 \mathrm{yr} .\end{array}$ & $\begin{array}{c}\text { Died aged } 48 \text { yr. } \\
1948 \\
\text { Died aged } 51 \text { yr. } \\
1950-1\end{array}$ \\
\hline MacMillan (1951) & $\begin{array}{l}\text { Female } \\
\text { Daughter }\end{array}$ & $\begin{array}{l}2 \text { sisters died 'T.B.' } \\
1 \text { st ill only } 24 \text { days } \\
2 \text { nd ill only } 15 \text { days } \\
2 \text { sisters normal } \\
1 \text { brother normal }\end{array}$ & F & $\begin{array}{l}30 \text { yr. } \\
49 \text { yr. } \\
\text { dyspnoea } 1 \\
\text { 'Adult' }\end{array}$ & $\begin{array}{l}1919 \\
1936 \\
1945\end{array}$ & Chronic & $1 \mathrm{yr}$. & $\begin{array}{l}\text { Died aged } 50 \mathrm{yr} \text {. } \\
1937 \\
\text { Age not given } \\
\text { Died } 1947\end{array}$ \\
\hline $\begin{array}{l}\text { MacMillan (1951) } \\
\text { MacMillan (1951) }\end{array}$ & $\begin{array}{l}\text { Female } \\
\text { Elder sister }\end{array}$ & $\begin{array}{l}\text { Non-identical twin } \\
\text { sister normal } \\
3 \text { brothers alive } \\
\text { and well } \\
\end{array}$ & $\mathbf{F}$ & $\begin{array}{l}30 \text { yr. } \quad \text { x-ray } \\
\text { dyspnoea } \\
37 \text { yr. } \\
\text { dyspnoea }\end{array}$ & $\begin{array}{l}1938 \\
1947 \\
1939\end{array}$ & $\begin{array}{l}\text { Subacute } \\
\text { Chronic }\end{array}$ & $2 \mathrm{yr}$. & $\begin{array}{l}\text { Died aged } 41 \mathrm{yr} . \\
1949 \\
\text { Alive in } 1951\end{array}$ \\
\hline $\begin{array}{l}\text { Schechter (1953) } \\
\text { Wildberger and } \\
\text { Barclay (1955) }\end{array}$ & $\begin{array}{l}\text { Male } \\
\text { Elder brother }\end{array}$ & $\left\{\begin{array}{l}6 \text { siblings ; none } \\
\text { had significant } \\
\text { chest disease }\end{array}\right.$ & $\begin{array}{l}\mathbf{M} \\
\mathbf{M}\end{array}$ & $\begin{array}{l}33 \mathrm{yr} . \\
40 \mathrm{yt} . \mathrm{x}-\mathrm{ray} \\
\text { dyspnoea }\end{array}$ & $\begin{array}{l}1948 \\
1942 \\
1953\end{array}$ & Subacute & $\begin{array}{l}5 \mathrm{yr} . \\
1 \mathrm{yr} .\end{array}$ & $\begin{array}{c}\text { Died aged } 38 \mathrm{yr} . \\
1953 \\
\text { Died aged } 52 \mathrm{yr} . \\
1954\end{array}$ \\
\hline $\begin{array}{l}\text { Rubin and Lubliner } \\
\text { (1957) } \\
\text { Rubin and Lubliner } \\
\text { (1957) }\end{array}$ & $\begin{array}{l}\text { Female } \\
\text { Sister }\end{array}$ & $\begin{array}{l}\text { Family history of } \\
\text { allergies }\end{array}$ & $\begin{array}{l}\mathbf{F} \\
\mathbf{F}\end{array}$ & $\begin{array}{l}57 \mathrm{yr} . \\
40 \mathrm{yr} .\end{array}$ & $\begin{array}{l}1950 \\
1948\end{array}$ & $\begin{array}{l}\text { Subacute } \\
\text { Subacute }\end{array}$ & $\begin{array}{l}1 \mathrm{yr} . \\
2 \mathrm{yr} .\end{array}$ & $\begin{array}{c}\text { Died aged } 58 \mathrm{yr} . \\
1951 \\
\text { Died aged } 42 \mathrm{yr} . \\
1950\end{array}$ \\
\hline $\begin{array}{l}\text { McKusick and } \\
\text { Fisher (1958) } \\
\text { McKusick and } \\
\text { Fisher (1958) }\end{array}$ & $\begin{array}{l}\text { Male } \\
\text { Brother }\end{array}$ & $\begin{array}{l}1 \text { son normal } \\
1 \text { brother normal } \\
1 \text { sister normal }\end{array}$ & $\begin{array}{l}\mathbf{M} \\
\mathbf{M}\end{array}$ & $\begin{array}{l}28 \mathrm{yr} . \\
37 \mathrm{yr} .\end{array}$ & $\begin{array}{l}1946 \\
1951\end{array}$ & $\begin{array}{l}\text { Chronic } \\
\text { Chronic }\end{array}$ & $\begin{array}{l}4 \mathrm{yr} . \\
3 \mathrm{yr} .\end{array}$ & $\begin{array}{c}\text { Died aged } 32 \mathrm{yr} . \\
1950 \\
\text { Died aged } 40 \mathrm{yr} . \\
1954\end{array}$ \\
\hline $\begin{array}{l}\text { Donohue et al. } \\
(1959) \\
\text { Donohue et al. } \\
(1959) \\
\text { Donohue et al. } \\
(1959)\end{array}$ & $\begin{array}{l}\text { Male (married) (a) } \\
\text { Brother }(b) \\
\text { Niece }(c) \\
\text { Grand-niece }(d) \\
\text { Grandson }(e)\end{array}$ & $\begin{array}{l}\text { Brother of }(a) \\
\text { Daughter of }(b) \\
\text { Daughter of }(c) \\
-\quad \text { of }(a) \\
-\quad \text { of }(a) \\
\text { daughter of }(e) \\
\text { of }(a) \\
-\quad \text { of }(a)\end{array}$ & $\begin{array}{l}\mathbf{F} \\
\mathbf{F} \\
\mathbf{M}\end{array}$ & $\begin{array}{l}\text { ? } \\
36 \text { yr. } \\
\text { bronchitis } \\
46 \text { yr. x-ray } \\
34 \text { yr. x-ray } \\
8 \mathrm{mth} \text {. } \\
13 \mathrm{yr} \text {. x-ray } \\
27 \mathrm{yr} \text {. } \\
6 \mathrm{msn} \text { moea } \\
9 \frac{1}{2} \mathrm{mth} . \\
4 \mathrm{mth} .\end{array}$ & $\begin{array}{c}\text { s } 1924 \\
1934 \\
1952 \\
1944 \\
1942 \\
1956 \\
1955 \\
1958 \\
1959\end{array}$ & \begin{tabular}{|l|} 
Chronic \\
Acute \\
Acute on chronic
\end{tabular} & $\begin{array}{l}\text { Many yr. } \\
1 \mathrm{mth} \text {. } \\
2 \mathrm{yr} \text {. }\end{array}$ & $\begin{array}{l}\text { Died aged } 51 \mathrm{yr} . \\
1932 \\
\text { Died aged } 52 \mathrm{yr} . \\
1940 \\
\text { Alive aged } 41 \mathrm{yr} . \\
1959 \\
\text { Died aged } 9 \mathrm{mth} . \\
1944 \\
\text { Alive aged } 29 \mathrm{yr} . \\
1958 \\
\text { Died aged } 6 \mathrm{mth} . \\
1955 \\
\text { Died aged } 12 \frac{1}{2} \mathrm{mth} . \\
1958 \\
\text { Alive } 1959 \\
\end{array}$ \\
\hline $\begin{array}{l}\text { Donohue et al. } \\
(1959) \\
\text { Donohue et al. } \\
(1959)\end{array}$ & $\begin{array}{l}\text { Male } \\
\text { Niece }\end{array}$ & $\begin{array}{l}4 \text { siblings normal } \\
3 \text { siblings normal }\end{array}$ & $\begin{array}{l}\mathbf{M} \\
\mathbf{F}\end{array}$ & $\begin{array}{l}35 \mathrm{yr} . \\
5 \mathrm{wk} .\end{array}$ & $\begin{array}{l}1942 \\
1952\end{array}$ & $\begin{array}{l}\text { Chronic } \\
\text { Subacute }\end{array}$ & $\begin{array}{l}10 \mathrm{yr} . \\
17 \mathrm{mth} \text {. }\end{array}$ & $\begin{array}{c}\text { Died aged } 45 \mathrm{yr} . \\
1952 \\
\text { Died aged } 18 \mathrm{mth} . \\
1953\end{array}$ \\
\hline $\begin{array}{l}\text { Appelman and } \\
\text { Buytendijk (1961) } \\
\text { Appelman and } \\
\text { Buytendijk (1961) } \\
\\
\text { Appelman and } \\
\text { Buytendijk (1961) } \\
\text { Appelman and } \\
\text { Buytendijk (1961) }\end{array}$ & $\begin{array}{l}\text { Female } \\
\text { Son } \\
\text { 1st daughter } \\
\text { 2nd daughter }\end{array}$ & $\begin{array}{l}\text { Her } 2 \text { children } \\
\text { normal }\end{array}$ & $\begin{array}{l}\mathbf{F} \\
\mathbf{M} \\
\mathbf{F} \\
\mathbf{F}\end{array}$ & $\begin{array}{l}\text { ? } \\
12 \mathrm{yr} . \quad \mathrm{x} \text {-ray } \\
21 \mathrm{yr} \text {. } \\
\text { dyspnoea }\end{array}$ & $\begin{array}{l}1949 \\
1958 \\
1956\end{array}$ & $\begin{array}{l}\text { Chronic } \\
\text { Subacute chronic }\end{array}$ & $3 \mathrm{yr}$. & $\begin{array}{l}\text { Died aged } 32 \mathrm{yr} \text {. } \\
\text { Died aged } 24 \mathrm{yr} \text {. } \\
1961 \\
\text { Died aged } 10 \mathrm{yr} \text {. } \\
\text { Alive } 1961\end{array}$ \\
\hline
\end{tabular}

† Where different. 
in the E.S.R. and gamma globulin fraction during each relapse suggests that the fibrosis of the lungs and anaemia may both be manifestations of an auto-immune condition. None of the patients had arthritis or positive serological tests for rheumatoid disease. The presence of a leukaemoid reaction is also interesting, particularly in view of the history of acute leukaemia in the sister who died in 1942; this suggests the possibility of some genetic leucocyte abnormality. No significant anaemia was found in cases 2 and 3 , and when a leucocytosis occurred it was usually in response to a secondary chest infection.

\section{DISCUSSION}

The first report in the literature appears to be that by Sandoz (1907) (Table I), in which he described a disease of the lungs which caused the death of two twin sisters at the age of 18 within 18 and six months respectively of the onset of dyspnoea. Pyrexia, tachycardia, and clubbing were noted during the illness, and necropsy revealed a sub-pleural zone of bullous emphysema, cystic dilatation of the terminal bronchi, and chronic inflammatory infiltration throughout the lungs.

The first authenticated report of the familial disease was by Peabody, Peabody, Hayes, and Hayes (1950) and MacMillan (1951), who described its occurrence in identical twin sisters who had lived apart from one another for many years. The first developed symptoms at the age of 44 , the diagnosis being made the following year when her dyspnoea worsened and the chest radiograph showed diffuse pulmonary fibrosis. She remained in reasonably good health for three years, but then deteriorated steadily, and at the age of 48 died of respiratory insufficiency. The second twin's illness presented with dyspnoea a year earlier, at the age of 43 , but the illness did not follow such a rapid course, and although the chest radiographs showed increasing pulmonary fibrosis she lived until the age of 50 .

Further cases were reported later by MacMillan (1951), Schechter (1953), and Wildberger and Barclay (1955), and, in a very comprehensive review, Rubin and Lubliner (1957) noted that, of the 54 cases of Hamman-Rich disease so far reported in the literature, six had occurred in siblings and they described a further two cases in sisters. One year later McKusick and Fisher (1958) reported three cases of progressive pulmonary fibrosis. Two were brothers, both of whom died, one of cor pulmonale at the age of 32 , the other at the age of 40 of progressive diffuse pulmonary fibrosis and bronchial carcin- oma. The third, a 53-year-old man, was not related but was of interest in that he, too, was found at necropsy to have a bronchial neoplasm associated with the pulmonary fibrosis. Donohue, Laski, Uchida, and Munn (1959) made a specific on study of the subject and found there was a definite clinical and pathological entity which, because of its definite genetic transmission, should be more specifically designated, and they suggested the descriptive term 'familial cystic fibrosis of the $\frac{\vec{x}}{x}$ lungs' or 'familial fibrocystic pulmonary dysplasia'. Details were then given of a further 10 cases. Eight were found in four generations of one $\dot{c}$ family group, and in a very well documented $\vec{G}$ report all the clinical and pathological findings $O$ are recorded together with details of the whole family tree. Similar information was given about $z$ a man and his niece from another family, both of whom died at the age of 45 years and 18 months respectively.

Four of these 10 patients died in infancy and all showed, except for a few minor variations, the $\vec{\varnothing}$ same fundamental picture not unlike that seen in + ordinary cases of interstitial pneumonitis.

Another family has now been reported by Appelman and Buytendijk (1961). The mother died at the age of 32 of what, at necropsy, was described as chronic interstitial pneumonia with inter-alveolar localization. One year after the mother's death, a daughter died at the age of 10 ; a necropsy was not made, but the chest radiograph was considered to show Hamman-Rich type fibrosis. More details are given of the brother who was born in 1937. At the age of 4 years the chest radiograph was normal, but eight years later, after an attack of diphtheria, the radiograph showed a fine reticulated appearance ; the Mantoux was negative and crepitations were a feature $\delta$ on auscultation. Three years later the chest radiograph showed slightly more shadowing and six years later, after a pneumonic illness, dyspnoea developed. A lung biopsy was performed and $\frac{D}{O}$ showed histological evidence of Hamman-Rich disease. On prednisolone therapy there was a $N$ marked symptomatic improvement, and two years $N$ later the patient was still quite well though the $N$ radiograph had not changed at all. After his death $\omega$ in 1961 necropsy confirmed the clinical diagnosis of Hamman-Rich syndrome. An examination of $\stackrel{\circ}{\subset}$ the family at this stage showed that a second sister had increased lung markings in the radiograph, and subsequently dyspnoea developed and radiologically the lungs showed the typical interstitial $\stackrel{\circ}{\mathbb{D}}$

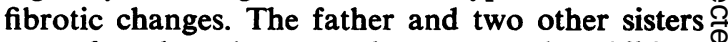
were found to be normal, as were the children $\varrho$ of the second sister who developed the disease.? 
The father subsequently re-married and had four children-one son and three daughters-but a review of this entire family showed no evidence of the disease. As the first wife was not related to her husband, and the disease had not oscurred in her predecessors, it was considered that she was the source of the new dominant mutation which she then passed on to approximately half of her children.

The present three cases, with the 28 previously reported, brings the total of familial cases recorded to 31 . There is now clearly sufficient evidence to show that liability to diffuse interstitial pulmonary fibrosis can be inherited and warrants, in such cases, the present descriptive term.

INHERITANCE These cases confirm that, at least in a proportion of patients, the disease may be genetically determined, but there is insufficient evidence as yet to indicate the precise mode of transmission. Donohue et al. (1959), after their detailed study of two family groups, considered that cystic fibrosis of the lung was transmitted as a dominant gene with reduced penetrance; but they thought there was, as yet, insufficient evidence to decide whether inheritance is of the common autosomal dominant type or the rare sexlinked dominant. The preponderance of females affected in the familial group lends support to the hypothesis of sex linkage. Of the 31 cases, 22 $(71 \%)$ were female and nine $(29 \%)$ male, showing a preponderance of females over males of $2: 1$, which contrasts with the equal sex incidence of all reported cases. On the other hand, a proven example of transmission of the disease from father to son would indicate that the disease is inherited as a simple autosomal dominant gene.

In the most recent review, Livingstone, Lewis, Reid, and Jefferson (1964), in a detailed study of 45 patients with histologically proven diffuse interstitial pulmonary fibrosis of unknown origin, found no suggestive history of the syndrome in other members of the family but did not indicate whether all the relatives had been subjected to radiological examination. This seems important, for in six of the 29 familial cases now recorded, radiological evidence of interstitial pulmonary fibrosis preceded by some years the onset of shortness of breath.

Perhaps now that it is known that heredity plays a part in the causation of the condition further family studies may be forthcoming to shed more light on the mode of transmission and, in so doing, help to elucidate the recently recognized association between interstitial pulmonary fibrosis and rheumatoid arthritis and other collagen diseases.

\section{SUMMARY}

The familial occurrence of diffuse interstitial pulmonary fibrosis is recorded in three members of one family, the first report from this country. Cases previously reported in the literature are reviewed, and the mode of transmission is discussed. Evidence is presented to show that radiological evidence of disease may precede the onset of symptoms, and the suggestion is made that further examples of the familial type of the disease may be discovered by routine clinical and radiological examination of the patients' relatives.

I am indebted to Professor J. Gough for his histological reports, the giant section and microphotographs, and for much helpful advice; to Dr. R. Salm for translations and help with the manuscript; and to Dr. Eileen E. Wood for haematological and biochemical data. Dr. G. Sheers, of the Mass Radiography Unit, Plymouth, generously helped to examine the relatives, and Dr. J. D. Bruce kindly arranged the necropsy of the patient who died at home.

Figures 2 and 9 were prepared by Mr. P. J. Stinchcombe, photographer to the Pathological Department, Welsh National School of Medicine, and Miss Phyllis M. Coleman, Redruth, provided the rest of the photographs.

\section{REFERENCES}

Appelman, A. C., and Buytendijk, H. J. (1961). Chronische interstitiële pneumonie (Syndroom van Hamman-Rich) in een families. Ned. T. Geneesk, 105, 1928 .

Donohue, W. L., Laski, B., Uchida, I., and Munn, J. D. (1959). Familial fibrocystic pulmonary dysplasia and its relation to the Hamman-Rich syndrome. Pediatrics, 24, 786.

Gough, J. (1959). Honeycomb lung. Bull. Post-Grad. Comm. Med. Univ. Sydney, 15, 277.

Hamman, L., and Rich, A. R. (1944). Acute diffuse interstitial fibrosis of the lungs. Bull. Johns Hopk. Hosp., 74, 177.

Livingstone, J. L., Lewis, J. G., Reid, L., and Jefferson, K. E., (1964). Diffuse interstitial pulmonary fibrosis. Quart. J. Med., 33, 71.

McKusick, V. A. and Fisher, A. M. (1958). Congenital cystic disease of the lung with progressive pulmonary fibrosis and carcinomatosis. Ann. intern. Med. 48, 774.

Goodman, R. M., and Danks, D. M. (1963). Genetic aspects of respiratory disease. Arch. environm. Hlth, 6, 25.

MacMillan, J. M. (1951). Familial pulmonary fibrosis. Dis. Chest, 20. 426 .

Peabody, J. W., Peabody, J. W. Jr., Hayes, E. W., and Hayes, E. W. Jr. (1950). Idiopathic pulmonary fibrosis : its occurrence in Ir. (1950). Idiopathic pulmonary twin sisters. Ibid., 18, 330 .

Rubin, E. H., and Lubliner, R. (1957). The Hamman-Rich syndrome : review of the literature and analysis of 15 cases. Medicine (Baltimore), 36, 397.

Sandoz, E. (1907). Uber zwei Fälle von fötaler Bronchektasie. Beitr. path. Anat., 41, 495.

Scadding, J. G. (1960). Chronic diffuse interstitial fibrosis of the lungs. Brit. med. J., 1, 443.

Schechter, M. M. (1953). Diffuse interstitial fibrosis of the lungs. Amer. Rev. Tuberc., 68, 603.

Wildberger, H. L., and Barclay, W. R. (1955). Diffuse interstitial pulmonary fibrosis. Ann. intern. Med., 43, 1127. 